Tuchkina I. O., Pylypenko N. S., Tuchkina M. Yu., Piontkovska O. V., Romanova N. V., Kachaylo I. A. Somatic status of adolescent girls with gynecological disorders born with low and excessive weight. Journal of Education, Health and Sport. 2022;12(1):34-42. eISSN 2391-8306. DOI http://dx.doi.org/10.12775/JEHS.2022.12.01.003

https://apcz.umk.pl/JEHS/article/view/JEHS.2022.12.01.003

https://zenodo.org/record/5838193

The journal has had 40 points in Ministry of Education and Science of Poland parametric evaluation. Annex to the announcement of the Minister of Education and Science of December 1, 2021. No. 32343. Has a Journal's Unique Identifier: 201159. Scientific disciplines assigned: Physical Culture Sciences (Field of Medical sciences and health sciences); Health Sciences (Field of Medical Sciences and Health Sciences).

Punkty Ministerialne z 2019 - aktualny rok 40 punktów. Zalącznik do komunikatu Ministra Edukacji i Nauki z dnia 1 grudnia 2021 r. Lp. 32343. Posiada Unikatowy Identyfikator Czasopisma: 201159. Przypisane dyscypliny naukowe:Nauki o kulturze fizycznej (Dziedzina nauk medycznych i nauk o zdrowiu); Nauki o zdrowiu (Dziedzina nauk medycznych i nauk o zdrowiu).

(1) The Authors 2022;

This article is published with open access at Licensee Open Journal Systems of Nicolaus Copernicus University in Torun, Poland

Open Access. This article is distributed under the terms of the Creative Commons Attribution Noncommercial License which permits any noncommercial use, distribution, and reproduction in any medium,

provided the original author un sand source are credited. This is an open access article licensed under the terms of the Creative Commons Attribution Non commercial license Share alike
(http://creativecommons.org/icenses/by-nc-sa/4.0/) which permits unrestricted, non commercial use, distribution and reproduction in any medium, provided the work is properly cited. The authors declare that there is no conflict of interests regarding the publication of this paper.

Received: 15.12.2021. Revised: 25.12.2021. Accepted: 11.01.2022.

\title{
SOMATIC STATUS OF ADOLESCENT GIRLS WITH GYNECOLOGICAL DISORDERS BORN WITH LOW AND EXCESSIVE WEIGHT
}

\author{
I. O. Tuchkina, N. S. Pylypenko, M. Yu. Tuchkina, O. V. Piontkovska, N. V. Romanova, \\ I. A. Kachaylo
}

Kharkiv National Medical University, Kharkiv, Ukraine

Natalia Serhiivna Pylypenko - Corresponding author; nataliya.pele@ gmail.com; ORCID: https://orcid.org/0000-0002-2417-8765; Postgraduate student, Kharkiv National Medical University, Department of Obstetrics, Gynecology and Pediatric Gynecology, Kharkiv, Ukraine. Kharkiv National Medical University, Nauki Avenu 4, Kharkiv, Ukraine. +380958105662, nataliya.pele@ gmail.com

Iryna Oleksiivna Tuchkina; ira.tuch@gmail.com; ORCID: https://orcid.org/0000-0003-4280-1474 Doctor of Medical Sciences, Professor, Kharkiv National Medical University, Chief of Department of Obstetrics, Gynecology and Pediatric Gynecology, Kharkiv, Ukraine.

Maryna Yuriivna Tuchkina; tuchkmarisha@gmail.com;

ORCID: https://orcid.org/0000-0002- 9903-1784; Assistant of the Department of Neurology No. 1, Candidate of Medical Sciences, Kharkiv National Medical University, Kharkiv, Ukraine.

Oksana Volodymyrivna Piontkovska; odkb1@ukr.net;

ORCID: https://orcid.org/0000-0003- 3133-5746; Doctor of Medical Sciences, Professor, Kharkiv National Medical University, Department of Obstetrics, Gynecology and Pediatric Gynecology, Kharkiv, Ukraine. Chief of the Kharkiv Regional Clinical Children's Hospital No. 1

Nataliia Vikrorivna Romanova; odkb1@ ukr.net; ORCID: https://orcid.org/0000-0003- 2681-3539 Head of the Department of Surgery No. 4, Kharkiv Regional Clinical Children's Hospital No. 1, Kharkiv, Ukraine

Iryna Anatoliivna Kachailo; irina.kachailo@ukr.net;

ORCID: https://orcid.org/0000-0002-9892-4353

Candidate of Medical Sciences, Assistant, Kharkiv National Medical University,

Department of Obstetrics, Gynecology and Pediatric Gynecology, Kharkiv, Ukraine. 


\begin{abstract}
In modern conditions, health problems (somatic, reproductive, mental) of adolescent girls occupy a special place in the health care system, as a reserve in reducing maternal and infant mortality, maintaining the fertility of the expectant mother.

The aim. To study the frequency and character of extragenital diseases of adolescent girls with gynecological pathology, born with low and excessive body weight.

Materials and methods. The project design is a population-based prospective cohort study. To achieve the goal and the implementation of the tasks, a prospective examination of girls and adolescent girls born with deficiency or excess body weight was carried out. The sample size was 77 people. Additionally, statistical processing was carried out using the Excell software.

Results. Thus, the study of somatic health indicates its deterioration in the groups of girls born with polar values of body weight. In groups 1 and 3, infectious diseases were identified, which can serve as a starting point in the development of reproductive system disorders. In girls of group 1, mumps prevailed (20.0\%), which could cause damage to the follicular apparatus, while in group 3, girls were more likely to have influenza (25.8\%), the virus of which has a damaging effect not only on the structure of the ovaries, but also on endometrium.
\end{abstract}

Conclusions. Comparative analysis of the structure of somatic morbidity made it possible to identify the most significant pathology characteristic of each of the groups. Girls born with a large body weight have an increased risk of endocrine pathology. In girls born with low body weight, somatic diseases associated with manifestations of diseases of the musculoskeletal system prevail.

This dictates the need to single out girls born with polar values of body weight in the risk group for the development of somatic pathology and requires complex therapeutic and prophylactic measures.

Key words: reproductive system of girls and adolescent girls; somatic health; extragenital pathology; macrosomia; intrauterine growth retardation syndrome.

Introduction. The problem of preserving and strengthening the reproductive health of adolescent girls born with underweight is extremely important for the state of reproductive function in the future. It is known that the demographic situation that is currently observed in Ukraine is determined by the low reproductive health indicators of adolescent girls. One of the most pressing problems of the modern health care system is the preservation of the 
reproductive potential of adolescents. After all, an important condition for the development of society and a socio - economic indicator is a woman's reproductive health. The first manifestations of impaired functioning of the genital area, which further lead to a decrease in fertility in adulthood, are noted precisely in the period of puberty [1, 2, 3].

Features of somatic health in adolescents are determined by two main processes occurring at this age. This is a pubertal restructuring of regulatory structures that provides physical, sexual and psychosexual development, on the one hand, and psychosocial development entering its final phase, on the other. Based on the theory of systems genesis, all changes occurring in the body of adolescent girls, including those leading to specific features in diseases of internal organs, should be considered from the point of view of the formation of the reproductive sphere $[4,5]$.

There is a significant relationship between the state of somatic and reproductive health of adolescents. In somatically healthy girls, the frequency of gynecological disorders is several times lower than in those with extragenital pathology.The most typical combination of somatic diseases and menstrual dysfunction (MFD) for adolescents have common causes and mechanisms of their formation [6].

The relationship between the somatic sphere and sexual development is carried out at two levels. Central - through the hypothalamic mechanisms by regulating the visceral systems and the reproductive sphere in accordance with the mechanisms of direct and feedback. Local - according to the type of "internal organ-ovary". At the level of interorgan interaction, the links between the ovaries and the liver, kidneys, gastrointestinal tract and the respiratory system seem to be the closest [7].

Reproductive system disorders can be caused, for example, by endocrine diseases, endogenous intoxication, metabolic disorders, chronic liver, kidney and gastrointestinal tract diseases. Somatic diseases can lead to shifts in physical and psychosexual development [8]. Diseases of internal organs that form or intensify against this background (anemia, hemorrhagic diathesis, disorders of the liver and gastrointestinal tract, kidney disease) and NFM aggravate the course of each other. From the point of view of a teenage doctor, NFM in girls should be considered as an easily detectable marker of systemic disorders. Adolescents with ovarian dysfunction require a thorough physical examination, even if they consider themselves to be completely healthy $[9,10]$.

The question of the influence of somatic health on the formation of menstrual function during puberty in adolescent girls who were born with deficiency or excess body weight remains poorly understood [11].In this regard, it seemed important to us to study the features 
of the somatic status in adolescent girls with polar values of body weight at birth against the background of gynecological pathology. Since the timely correction of the arising disturbances in the regulation of the ovarian-menstrual cycle in adolescents, as well as the strengthening of the somatic health of girls, can prevent subsequent problems associated with reproductive health.

The aim. To study the frequency and character of extragenital diseases of adolescent girls with gynecological pathology, born with low and overweight.

Materials and methods. The study was carried out at the Department of Obstetrics, Gynecology and Pediatric Gynecology of Kharkiv National Medical University ("Regional Children's Clinical Hospital No. 1" - the clinical base of the department). The study was approved by the Ethics and Bioethics Commission of KNMU and met the ethical standards of the Bioethical Committee, developed in accordance with the Declaration of Helsinki of the World Association "Ethical Principles for Scientific Medical Research with Human Participation" as amended in 2013. All patients provided written informed consent to participate in the study.

The study involved 77 adolescent girls from 13 to 18 years old. Group 1 included 26 girls born with a body weight of less than $2900.0 \mathrm{~g}$. The second group included 27 girls born with a body weight of $3000-3700.0$ g. The third group was formed by 24 adolescent girls with a birth weight of more than $3800.0 \mathrm{~g}$.

Inclusion criteria: voluntary informed consent of patients and their parents to conduct the study, accurate information about body weight at birth, birth at 37-41 weeks of gestation, the presence of gynecological pathology in the absence of anomalies in the development of genital organs. Excluded from the study were patients born at less than 37 weeks or more than 41 weeks of multiple pregnancies. In the course of the work, an individual card was filled in for each patient, in which passport data, age, data of general and gynecological anamnesis, including concomitant gynecological and extragenital pathology, results of anthropometric, clinical laboratory and special examination methods were noted.

During the screening examination of adolescent girls, physical parameters (height, body weight) were determined, various complaints were clarified, indicating the possibility of pathology of the reproductive system, as well as the presence of acute or chronic somatic diseases. At the same stage, an assessment was made of the timing of the onset and the degree of development of secondary sexual characteristics. After the completion of this stage, a sample was formed for in-depth clinical and laboratory research and verification of the somatic and gynecological problems of patients. 
Statistical data processing was carried out using the Statistica 6.0 and Microsoft Excel Office 10 software package. Hypotheses about the equality of the two means were tested using the Student's t-test. The measurement was considered reliable at $p<0.05$. In the absence of a normal distribution in the studied samples, nonparametric methods were used to compare the groups. To compare two independent samples, the Wilcoxon-Mann-Whitney U test was used. The statistical significance of differences between qualitative characteristics was assessed using the $\chi^{2}$ test. The nature and severity of relationships between different indicators was determined using a simple and rank correlation according to Spearman. Differences were considered statistically significant at $\mathrm{p}<0.05$.

Results. The structure and frequency of somatic pathology in the comparison groups at the time of examination are presented below.

Table 1

Comparative characteristics of the structure of somatic morbidity

\begin{tabular}{|l|c|c|c|}
\hline \multicolumn{1}{|c|}{ Pathology } & 1 group & 2 group & 3 group \\
\cline { 2 - 4 } & $\mathbf{p} \pm \mathbf{m}$ & $\mathbf{p} \pm \mathbf{m}$ & $\mathbf{p} \pm \mathbf{m}$ \\
\hline without & $10,0 \pm 2,3$ & $18,7 \pm 2,9$ & $12,9 \pm 2,5$ \\
\hline Allergic diseases & $22,47 \pm 3,15$ & $14,8 \pm 2,5$ & $27,9 \pm 3,1$ \\
\hline Infectious diseases & $20,38 \pm 4,77$ & $15,09 \pm 2,54$ & $28,56 \pm 3,16$ \\
\hline $\begin{array}{l}\text { Diseases of the ear, throat and } \\
\text { nose }\end{array}$ & $13,98 \pm 3,98$ & $8,57 \pm 2,24$ & $15,89 \pm 2,97$ \\
\hline Respiratory tract diseases & $23,25 \pm 2,76$ & $14,37 \pm 2,15$ & $21,56 \pm 3,18$ \\
\hline Diseases of the endocrine system & - & $1,65 \pm 1,2$ & $8,56 \pm 2,12$ \\
\hline $\begin{array}{l}\text { Pathology of the hepatobiliary } \\
\text { system }\end{array}$ & $5,78 \pm 1,26$ & $1,7 \pm 0,78$ & $4,78 \pm 2,14$ \\
\hline $\begin{array}{l}\text { Diseases of the cardiovascular } \\
\text { system }\end{array}$ & $16,7 \pm 2,9$ & $1,6 \pm 0,89$ & $4,67 \pm 1,15$ \\
\hline Diseases of the organs of vision & $10,1 \pm 2,13$ & $1,6 \pm 0,9$ & - \\
\hline Pathology of the urinary system & $2,4 \pm 1,34$ & - & - \\
\hline Diseases of the nervous system & $16,7 \pm 2,76$ & $1,57 \pm 0,78$ & - \\
\hline
\end{tabular}

Only $10.0 \%$ of girls in group 1 and $12.9 \%$ in group 3 could be considered conditionally healthy, which significantly exceeded the data in group 2 . In these groups, there was a combination of several extragenital diseases.

A retrospective analysis of past childhood infectious diseases showed that girls in group $3(21.9 \pm 3.1 \%)$ had chickenpox 3.7 times more often than in group $1(5.9 \pm 1.8 \%)$, and in 2 the group did not have this pathology. 
The frequency of mumps was highest in group $1(20.0 \pm 3.1 \%)$, which was significantly more frequent than in group $2\left(8.8 \pm 2.1 \%, \mathrm{p}_{1-2}<0.01\right)$, and in group 3 the frequency of this pathology was $12.9 \pm 2.5 \%$.

The specific gravity of scarlet fever was significantly higher in group $3(21.9 \pm 3.1 \%)$ and 2.5 times higher than the frequency of this pathology in group $2\left(8.8 \pm 2.1 \%, \mathrm{p}_{2-3}<0.01\right)$. In group 1, the incidence of scarlet fever was $13.5 \pm 2.6 \%$.

Girls of $1(16.5 \pm 2.8 \%)$ and 3 groups $(17.4 \pm 2.8 \%)$ had measles with the same frequency, which was almost 2 times higher than this pathology in group $2\left(8.8 \pm 2.1 \%, \mathrm{p}_{1-}\right.$ ${ }_{2}<0.05$ and $\left.\mathrm{p}_{2-3}<0.05\right)$.

Frequent acute respiratory viral infections (ARVI) prevailed in the structure of somatic morbidity in all surveyed groups. A significant increase in this pathology was found in group $369.7 \pm 3.5 \%\left(\mathrm{p}_{2-3}<0.001\right)$, which is 1.6 times more often than in group 2, where ARVI accounts for $44.5 \pm 3.7 \%$. A similar situation was observed in group 1, where the incidence of ARVI was $56.5 \pm 3.8 \%\left(\mathrm{p}_{1-2}<0.05\right)$.

The frequency of otitis media in $1(23.5 \pm 3.3 \%)$ and $3(25.8 \pm 3.3 \%)$ groups was almost 2 times higher than in group $2\left(12.1 \pm 2.4 \%, \mathrm{p}_{1-2}<0.01\right.$ and $\left.\mathrm{p}_{2-3}<0.01\right)$.

The level of resistance of the organism in the compared groups has been analyzed. In the 1st group, a high level of body resistance (the presence of acute diseases no more than once a year, proceeding without complications and no more than 14 days) was detected in $38.8 \pm 3.7 \%$, average (acute diseases $2-3$ times a year) - in $35.9 \pm 3.7 \%$, decreased (acute diseases up to 8 times a year) - in $15.3 \pm 2.8 \%$ and sharply reduced (acute diseases are recorded 8 or more times a year) - in $10,0 \pm 2.8 \%$.

Table 2

Analysis of the level of body resistance in adolescent girls in the compared groups

\begin{tabular}{|l|c|c|c|c|}
\hline $\begin{array}{c}\text { Level } \\
\begin{array}{c}\text { resistance } \\
\text { organism }\end{array}\end{array}$ & 1 group & 2 group & 3 group & P \\
\cline { 2 - 4 } & $\mathbf{p} \pm \mathbf{m} \%$ & $\mathbf{p} \pm \mathbf{m} \%$ & $\mathbf{p} \pm \mathbf{m} \%$ & \\
\hline High & $38,8 \pm 3,7$ & $58,8 \pm 3,7$ & $44,4 \pm 3,7$ & $\begin{array}{c}\text { P } 1-2<0,001 \\
\mathbf{p}_{2-3}<0,01\end{array}$ \\
\hline Medium & $35,9 \pm 3,7$ & $34,1 \pm 3,5$ & $37,8 \pm 3,6$ & $\mathrm{p}>0,05$ \\
\hline Reduced & $15,3 \pm 2,8$ & $4,4 \pm 1,5$ & $11,8 \pm 2,4$ & $\begin{array}{c}\text { P } 1-2<0,01 \\
\text { P } 2-3<0,01\end{array}$ \\
\hline Sharply reduced & $10,0+2,8$ & $2,7 \pm 1,2$ & $6,7+1,9$ & $\mathrm{P} 1-2<0,05$ \\
\hline
\end{tabular}

A similar pattern can be traced in group 3, a high level of body resistance was noted in them in $44.4 \pm 3.7 \%$, average - in $37.1 \pm 3.6 \%$, decreased - in $11.8 \pm 2.4 \%$ and sharply reduced - 
in $6.7 \pm 1.9 \%$. The average level of resistance of the organism was approximately the same in all the examined groups and did not differ significantly.

The proportion of chronic diseases of the nasopharynx in group 1 was $16.5 \pm 2.8 \%$ and almost did not differ from the indicators of group $2(18.7 \pm 2.9 \%)$, but was 1.8 times lower than in group $3\left(30,3 \pm 3.5 \%, \mathrm{p}_{1-3}<0.01\right.$ and $\left.\mathrm{p}_{2-3}<0.05\right)$.

The frequency of bronchitis in $1(16.5 \pm 2.8 \%)$ and 3 groups $(17.4 \pm 2.8 \%)$ was almost 2 times higher than in group $2(9.9 \pm 2.2 \%)$. Every fourth girl in group 3 had pneumonia $(25.8 \pm 3.3 \%)$, which was 2 times more often than in group $1\left(13.5 \pm 2.6 \%, \mathrm{p}_{1-3}<0.01\right)$.

The second place in the structure of somatic pathology was occupied by allergic diseases, the frequency of which in group 3 was $34.8 \pm 3.6 \%$, and in group $1-23.5 \pm 3.3 \%$, which was 2 or more times higher than in group $2\left(14.8 \pm 2.6 \%, \mathrm{p}_{1-2}<0.05\right.$ and $\left.\mathrm{p}_{2-3}<0.001\right)$.

Analysis of endocrine pathology showed that endocrinopathies prevailed in group 3, among which the leading place was occupied by diabetes mellitus and impaired glucose tolerance $(12.9 \pm 2.5 \%)$, diagnosed 11.7 times more often than in group $2\left(1,1 \pm 0.8 \%, \mathrm{p}_{2}\right.$ $\left.{ }_{3}<0.001\right)$. In second place was thyroid pathology: hypothyroidism in $8.4 \pm 2.1 \%\left(\mathrm{p}_{1-3}<0.001\right.$ and $\left.\mathrm{p}_{2-3}<0.001\right)$, euthyroidism in $4.5 \pm 1.6 \%\left(\mathrm{p}_{1-3}<0.01\right.$ and $\left.\mathrm{p}_{2-3}<0.01\right)$. In contrast, no endocrine pathology was detected in group 1.The frequency of hepatitis in girls of group 3 was $4.5 \pm 1.6 \%$ versus $1.6 \pm 0.9 \%$ in group 2 , while this pathology was not found in peers of group $1\left(\mathrm{p}_{1-3}<0.01\right)$.

In group 1, there was a high incidence of somatic diseases, which are attributed to systemic phenotypic manifestations of undifferentiated forms of connective tissue dysplasia. The frequency of mitral valve prolapse and vegetative-vascular dystonia in them was $16.5 \pm 2.8 \%$ ( $\left.\mathrm{p}_{1-2}<0.001\right)$, which was 10 times more often than in group $2(1.6 \pm 0.9 \%)$. The frequency of myopia in group 1 was $10.0 \pm 2.3 \%$ versus $1.6 \pm 0.9 \%$ in group $2\left(\mathrm{p}_{1-2}<0.01\right)$. Disorders in the musculoskeletal system (scoliosis, flat feet) $-6.5 \pm 1.9 \%\left(\mathrm{p}_{1-2}<0.001\right)$ and nephroptosis $-2.4 \pm 1.2 \%\left(\mathrm{p}_{1-2}<0.05\right)$ were noted only in 1 group.

Conclusions. Thus, the study of somatic health indicates its deterioration in the groups of surveyed girls born with polar values of body weight. In adolescent girls with gynecological pathology, born with low and high body weight, infectious diseases have been identified that can trigger the development of disorders of the female reproductive system. In girls born with low birth weight, mumps prevailed (20.0\%), which could cause damage to the follicular apparatus, while in the group with high birth weight, girls were more likely to have influenza (25.8\%), the virus of which has a damaging effect. not only on the structure of the ovaries, but also on the endometrium. 
Comparative analysis of the structure of somatic morbidity made it possible to identify the most significant pathology characteristic of each of the groups. Girls born with a large body weight have an increased risk of endocrine pathology. In girls born with low body weight, somatic diseases associated with manifestations of pathology of the musculoskeletal system prevail.

This dictates the need to single out girls born with polar values of body weight in the risk group for the development of somatic pathology and requires complex therapeutic and prophylactic measures.

\section{References}

1. Wennerström EC, Simonsen J, Melbye M. Long-Term Survival of Individuals Born Small and Large for Gestational Age. PLoS One. 2015 Sep 21;10(9):e0138594. doi: 10.1371/journal.pone.0138594. PMID: 26390219; PMCID: PMC4577072.

2. Vikström J, Hammar M, Josefsson A, Bladh M, Sydsjö G. Birth characteristics in a clinical sample of women seeking infertility treatment: a case-control study. BMJ Open. 2014 Mar 10;4(3):e004197. doi: 10.1136/bmjopen-2013-004197. PMID: 24613821; PMCID: PMC3963097.

3. Garces A, Perez W, Harrison MS, Hwang KS, Nolen TL, Goldenberg RL, Patel AB, Hibberd PL, Lokangaka A, Tshefu A, Saleem S, Goudar SS, Derman RJ, Patterson J, Koso-Thomas M, McClure EM, Krebs NF, Hambidge KM. Association of parity with birthweight and neonatal death in five sites: The Global Network's Maternal Newborn Health Registry study. Reprod Health. 2020 Dec 17;17(Suppl 3):182. doi: 10.1186/s12978-02001025-3. PMID: 33334362; PMCID: PMC7745358.

4. Ma R, Luo Y, Wang J, Zhou Y, Sun H, Ren X, Xu Q, Zhang L, Zou L. Tenyear time trends in preterm birth during a sociodemographic transition period: a retrospective cohort study in Shenzhen, China. BMJ Open. 2020 Oct 20;10(10):e037266. doi: 10.1136/bmjopen-2020-037266. PMID: 33082182; PMCID: PMC7577040.

5. Bogdanova EA. Prakticheskaya ginekologiya molodykh [Practical gynecology of young people]. Moscow: "Medical book"; 2011. P. 238

6. Tuchkina M. Yu. Treatment of adolescent girls with abnormal uterine bleeding taking into account psychoemotional and vegetative status / Tuchkina I. A., Tuchkina M. Yu., Novikova A. A. // Journal of Education, Health and Sport.2019; 9 (5): 575-582.eISNN 23918306. DOI http://dx.doi.org/10.5281/zenodo. 3239459 http: //ojs.ukw.edu.pl/index.php/johs/article/view/7001 https://pbn.nauka.gov.pl/sednowebapp/works/915268 
7. Tuchkina M. Disorders of menstrual function in adolescents with autonomic dysfunction / I. Tuchkina, M.Tuchkina, I. Merenkova, O.Gnatenko, L.Dobrovolskaya // Abstract book of the 19th World Congress of PAG, 2020, P-105, p.34

8. Correction of disorders of the autonomic nervous system in adolescents with gynecological pathology / M. Tuchkina // Proceedings of the All-Ukrainian scientificpractical conference "Current issues of obstetrics, gynecology and reproductive medicine" October 20, 2017, Zaporozhye, Art. 24 - 25

9. Tuchkina I.O., Dobrovolskaya L.A., Tuchkina M.Yu. Clinical and diagnostic aspects of primary dysmenorrhea in adolescence // Medicine (Almaty). - 2016. - No 6 (168). R. 51-56.

10. Irina Tuchkina, Lyudmila Vygovskaya, Anastasia Novikova. Features of uterine blood flow in adolescents with abnormal uterine bleeding of puberty. J Clin Med Kaz. 2019; 4 (54): $21-24$

11. I.O.Tuchkina, L.A. Dobrovolska, LA Vyhivska, M.Yu. Tuchkina / A method of treating dysmenorrhea in adolescent girls // Patent for utility model №94513U publ.10.11.2015, effective from 10.11.2015, Ukraine. Z. № u201408487 dated 25.07.2014. Applicant and patent owner of KhNMU. 